\title{
U.N. REFORM AND THE INTERNATIONAL COURT OF JUSTICE: INTRODUCTORY STATEMENT
}

\author{
Ambassador Andrew Jacovides*
}

It is customary during anniversaries to devote some attention to introspection and stock taking. Looking back at my own writings on the subject of U.N. reform (during the fortieth, the fiftieth and now the sixtieth anniversary in 1985, 1995 and this year), I confirmed my long held conviction that the United Nations is indispensable and its Charter, in its basic provisions, has stood the test of time.

All Member States are legally bound by their signature to the United Nations Charter. If its principles and rules are often disregarded in practice, this is not the fault of the organization but of those Member States who fail to honour their solemn obligations. The Charter is based on sound foundations and has proven sufficiently flexible to allow, through progressive interpretation, substantial adjustments to meet emerging needs: peacekeeping and the limitations to domestic jurisdiction or sovereignty, especially in the protection of human rights, come readily to mind. While there is considerable room for improvement, restructuring and regeneration, the emphasis should not be on tinkering with the Charter but on organizational reforms. Even more importantly, there must be emphasis on implementing, effectively and consistently, its purposes and principles and more specifically the resolutions of its principal organs such as the Security Council and the General Assembly - a sore point, I might add, as a Cypriot who has seen numerous U.N. resolutions on Cyprus remain unimplemented. Obviously, there is considerable room for improvement in the Organization itself and in the Secretariat. Much can be done to eliminate cronyism and deadwood and prevent the erosion of the concept of the international civil servant who owes primary allegiance to the Organization. I refrain from going into specifics for this would go far beyond today's topic and the time available.

Last year and especially this year, on the occasion of the sixtieth anniversary of the U.N., considerable activity has taken place at the United Nations itself, at the U.S. Association for the U.N. (USUN), at learned societies such as the American Society of International Law (ASIL) and such

* Former 3-term elected member of the UN International Law Commission (1981-1996) and delegate of Cyprus to the Sixth (Legal) Committee (1960-2003). This article is a revised reproduction of oral remarks presented at the International Law Weekend 2005, held at the House of the Association of the Bar of the City of New York, from October 20 to 22, 2005. 
academic/political/diplomatic institutions as the Institute for the Study of Diplomacy (ISD) of Georgetown University, under the generic rubric of "UN Reform." A major study was also commissioned by the U.S. Congress on "American Interests and U.N. Reform" (issued on June 2, 2005 under the names of Newt Gingrich and George Mitchell) which makes several sound proposals. ${ }^{1}$

A major contribution was made by a High-Level Panel of sixteen distinguished panelists--some more distinguished than others-from different countries proposing 101 recommendations on U.N. reform, including defining international terrorism, regulating the use of force, restructuring the Security Council, abolishing the Trusteeship Council, revamping human rights, etc.

Secretary-General Kofi Annan, in turn, came out with his carefully considered report "In Larger Freedom" on March 21, 2005, in a significant effort to effectively respond to the call for adjusting the United Nations to the 21 st century needs, the more so in the wake of the debate on the legality of the Iraq war and the "Oil-for-Food" and other controversies currently burdening the Organization. ${ }^{2}$

Following considerable diplomatic activity in the past few months and facing the prospect of collapse because of competing interests and divergent views, especially on the highly controversial issue of the expansion of the Security Council, what could be rescued out of these major reform proposals was what was described as "The 2005 World Summit Outcome" (significantly not called a "Declaration"), adopted on September 15, 2005 by the High Level Plenary Meeting of the General Assembly. ${ }^{3}$ Even though falling far short of the earlier targets, it was a considerable achievement under the circumstances and a major effort is under way, spearheaded by President Eliasson, for it to serve as a stepping stone to meaningful reform in the areas it covers. This document was also described as "modest" (and, here, may I remind you of Sir Winston Churchill's saying of his political opponent, "Mr. Attlee is a very modest person-he has so much to be modest about!" Incidentally, Mr. Attlee was also described by Churchill as "a sheep in sheep's clothing"!). However, when it comes to references to international law and the rule of law the Outcome

1. See generally UNTTED STATES INSTITUTE OF PEACE, AMERICAN INTERESTS \& U.N. REFORM: REPORT OF THE TASK FORCE ON THE UNITED NATIONS (2005), available at http://www.usip.org/un/report/usip_un_report.pdf (last visited Mar. 8, 2006).

2. The Secretary-General, Report of the Secretary-General-In Larger Freedom: Towards Development, Security and Human Rights For All, U.N. Doc. A559/2005 (Mar. 21, 2005, available at http://daccessdds.un.org/doc/UNDOC/GEN/N05/270/78/PDF/N0527078.pdf?OpenElement (last visited Mar. 8, 2005) [hereinafter In Larger Freedom].

3. U.N. General Assembly, 2005 World Summit Outcome: Draft Resolution Referred to the HighLevel Plenary Meeting of the General Assembly by the General Assembly at its Fifty-Ninth Session, U.N. Doc. A/60/L.1, available at http://www.unis.unvienna.org/pdf/A60L.pdf (last visited Mar. 8, 2006) [hereinafter Outcome]. 
document is not so modest, with a multitude of such references in several parts of the text:

[W]e emphasize the obligations of States to settle their disputes in accordance with Chapter VI of the Charter, including, when appropriate, by the use of the International Court of Justice. All States should act in accordance with the Declaration on Principles of International Law concerning Friendly Relations and Cooperation Amongst States in accordance with the Charter. ${ }^{4}$

This is an important reminder that the contents of General Assembly Resolution 2625 XXV (1970)-in the adoption of which I played a very modest role-are still valid and relevant in 2005 as they were thirty-five years ago. ${ }^{5}$

More specifically and relevantly regarding today's topic, in Paragraph 134 of the 2005 World Summit Outcome, under the rubric "Rule of Law," it is stated that

Recognizing the need for universal adherence to and implementation of the rule of law at both the national and the international levels, we ... Recognize the important role of the International Court of Justice, the principal judicial organ of the United Nations, in adjudicating disputes among States, and the value of its work, call upon States that have not yet done so to consider accepting the jurisdiction of the Court in accordance with its Statute and consider means of strengthening the Court's work, including by supporting the Secretary-General's Trust Fund to Assist States in the Settlement of Disputes through the International Court of Justice on a voluntary basis. $^{6}$

When compared to the paper adopted, after much activity and debate but also much fanfare, by the High-Level Panel which, inexplicably and somewhat paradoxically, had nothing to say about the International Court of Justice while dealing with all five of the other principal organs of the United Nations (Security Council, General Assembly, Economic \& Social Council, Trusteeship Council, Secretariat), this text is substantial.

However, when compared to the equivalent paragraph 139 of the Secretary General's Report "In Larger Freedom" of March 21, 2005 (inserted after considerable efforts by the Court itself, U.N. Secretariat and others concerned

4. Id. I 73.

5. G.A. Res. 2625 (XXV), U.N. Doc. A/Res/2625(XXV) (Oct. 24, 1970), available at http://domino.un.org/pdfs/ARES2625XXV.pdf (last visited Mar. 8, 2006).

6. Outcome, supra note 3, II 134. 
by the evident lacuna in the High-Level Panel's text ....) it is less far reaching. Paragraph 139 of the Secretary General's report reads as follows:

The International Court of Justice lies at the centre of the international system for adjudicating disputes among States. In recent years, the Court's docket has grown significantly and a number of disputes have been settled but resources remain scarce. There is a need to consider means to strengthen the work of the Court. I urge those States that have not yet done so to consider recognizing the compulsory jurisdiction of the Court-generally, if possible or, failing that, at least in specific situations. I also urge all States to bear in mind, and make use of, the Court's advisory powers. Measures should also be taken, with the cooperation of litigating States, to improve the Court's working methods and reduce the length of its proceedings. ${ }^{\text {? }}$

When comparing the two texts, it should be noted that the World Summit Outcome document specifically makes reference to the Secretary-General's Trust Fund to Assist States in the Settlement of Disputes through the International Court of Justice (a positive element generally and, I imagine, particularly welcome by the distinguished lawyers who habitually practice before the I.C.J., sometimes irreverently referred to as "the usual suspects"!). But, in other respects, it is less precise and specific than the equivalent paragraph 139 of the Secretary-General's report. Most notably, there is no reference to the urging by the Secretary-General of "all parties to bear in mind, and make greater use of, the Court's advisory powers." 8

I recall that in a well thought out statement before the Sixth Committee of the General Assembly, on November 5, 2004, the President of the I.C.J, Judge Shi (following earlier suggestions to the same effect by, for instance, Judge Sehwebel when President of the I.C.J) made some significant suggestions on the underutilization by States of the ICJ advisory jurisdiction and its potential for expansion. He stated that: “. . . the advisory procedure provides the Court with a very real way of participating and contributing to the overall objectives of the United Nations. In addition to offering legal guidance to the requesting bodies, it can play a role in international dispute resolution." $\mathrm{He}$ also stated that: "the advisory procedure of the Court can also play an 'indirect'

7. In larger Freedom, supra note 2, $\mathbf{1} 139$.

8. Id.

9. H.E. Judge Shi Jiuyong (President to the International Court of Justice), Speech to the Sixth Committee of the General Assembly of the United Nations (Nov. 5, 2006), available at http://www.icjcij.org/icjwww/ipresscom/SPEECHES/iSpeech_President_Shi_Speeches_SixthCommittee _20041105.htm (last visited Mar. 8, 2006). 
part in preventing disputes and conflicts from developing, by clarifying the legal parameters within which a problem may be resolved."

Clarifying authoritatively by the I.C.J. of the legal aspects of pending international political disputes can go a long way towards lastingly resolving such disputes in a way consistent with the applicable rules of international law. For instance, in my earlier official capacity - and in the absence of a practical possibility for resorting to contentious proceedings-I have for many years advocated resort to the International Court of Justice, through a decision of the General Assembly or of the Security Council, for an Advisory Opinion clarifying the applicable rules of international law on several aspects of the Cyprus situation, such as the unilateral forcible intervention under Art. IV of the 1960 Treaty of Guarantee; the illegality of the $1983 \mathrm{UDI}$; the illegality of the establishment of settlers under the 1949 4th Geneva Convention and the 1998 Statute of the International Criminal Court; the applicable rules of State responsibility as, for instance, were applied on Iraq-Kuwait under S.C. Res. 687; violations of human rights etc. If this had been done, the contents of the recent U.N. (Annan V) plan would, I believe, have been drastically different and, quite possibly, it might not have been rejected, thereby becoming defunct and causing a backsliding of the process for a just solution to this long pending but solvable international problem.

I strongly feel that, in a comprehensive plan for a reformed and more effective United Nations, there exists ample room for such proposals for the fuller utilization of the International Court of Justice in general and of its advisory jurisdiction in particular. The recent Advisory Opinion on the Legal Consequences of the Construction of a Wall in the Occupied Palestinian Territory, July 9,2004 , furnishes a concrete such example..$^{10}$

In the same lecture Judge Shi, in a commendable attempt to stimulate debate among policymakers, cited a number of other possibilities. One is to broaden the field of application of the Court's advisory jurisdiction to intergovernmental organizations, perhaps through appropriate resolutions of the General Assembly or the Security Council. Another is to empower the Secretary-General on his own initiative to request advisory opinions, as already proposed by Mr. Boutros-Ghali in 1992 in his Agenda for Peace and by Mr. Kofi Annan in 2001. ${ }^{11}$ The issue was also raised in 1998 in the Charter

10. Advisory Opinion No. 131, Legal Consequences of the Construction of a Wall in the Occupied Palestinian Territory, 2004 I.C.J. 131 (July 9), available at http://www.icjcij.org/icjwww/idocket/imwp/imwp_advisory_opinion/imwp_advisory_opinion_20040709.htm (last visited Mar. 8, 2006).

11. The Secretary-General, Report of the Secretary-General $n$ the Work of the Organization-Prevention of Armed Conflict, U.N. Doc. A/55/985-S/2001/574, available at http://domino.un.org/unispal.nsf/0/b5bffcd5b649239585256caa006efab6?OpenDocument (last visited Mar. 8,2006 ). 
Committee Report (U.N. Doc. A/53/33). A third possibility is to authorize national supreme courts as well as international courts and tribunals to request advisory opinions on certain difficult or disputed questions of international law so as to allow for uniform interpretation for such rules and principles.

One other aspect I would very briefly comment on is the Court's composition. We have all witnessed the great interest and acrimony over the expansion of the Security Council in order to meet the realities of power in the 21 st century, an exercise the outcome of which is far from certain, and, yet, the Security Council was already expanded from eleven to fifteen members in the early sixties. By contrast, (under Art. 3 of its statute) the I.C.J. consists of fifteen judges in 2005 when the United Nations has 191 Member States, the same number as it had in 1945 with fifty-one Member States. During the same period other main organs of the U.N. have been expanded in order to meet emerging needs of representation. The ECOSOC expanded from eighteen to fifty-four, the Security Council (as I just said) from eleven to fifteen and now possibly to twenty-four, and the Secretary-General has acquired one Deputy and possibly another. The Law of the Sea Tribunal (set up in 1996 under the 1982 Law of the Sea Convention, currently some 148 States Parties) consists of twenty-one Judges. The International Law Commission was twice expanded from eighteen to twenty-five to the present thirty-four.

I recall that in the U.N. Charter Committee session of 1993, the issue was raised as something worth thinking about though not by a way of a specific proposal.

It would seem appropriate to also do the same in the context of U.N. reform, although I readily concede that, realistically, there is no support for any such initiative, in the I.C.J itself or politically among Member States and that different considerations apply to the Court's composition than in the composition of other bodies. But is this not something to reflect upon and, perhaps, after proper reflection, to reject it if it is not so warranted and its minuses outweigh its pluses? It is noteworthy, that in a footnote to his article in the July 2005 American Journal of International Law (at page 637) on Security Council Reform, Professor Yehuda Blum writes: "while the question of the Court's enlargement has not been raised by the [High-Level] panel (or subsequently), in the long term the Security Council enlargement may conceivably trigger demands for the Court's expansion as well."12

This concludes my contribution on "U.N. Reform and the I.C.J." It is my hope and expectation that, under the firm and able guidance of the General Assembly President, Jan Eliasson, sufficient progress will be made, with the World Summit Outcome 2005 document as a starting point, to meet at least 
some of the expectations of the international community for U.N. reform in general and more particularly of the International Court of Justice and on the rule of law, nationally and internationally. 